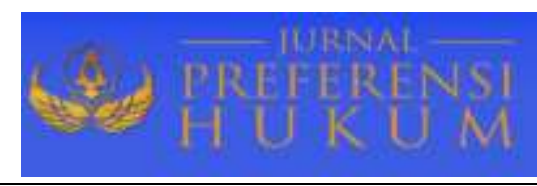

Jurnal Preferensi Hukum | ISSN: XXXX | E-ISSN: XXXX

Vol. 1, No. 2 - September 2020, Hal. 133-138| Available online at https://www.ejournal.warmadewa.ac.id/index.php/juprehum

DOI: http://doi.org/ 10.22225/jph.v1i2.2350.133-138

\title{
PUTUSAN PENGADILAN AGAMA BADUNG NOMOR 0166/PDT.G/2017/PA.BDG TENTANG CERAI GUGAT KARENA SALAH SATU PIHAK BERBEDA AGAMA
}

\author{
I Putu Wina Wirawan, I Nyoman Putu Budiartha, Ni Made Puspasutari Ujianti \\ Fakultas Hukum Universitas Warmadewa, Denpasar-Bali, Indonesia
}

\begin{abstract}
Abstrak
Perkawinan merupakan ikatan yang sakral karena di dalam ikatan perkawinan tersebut tidak hanya terdapat ikatan lahir batin atau jasmani saja tetapi juga ada ikatan rohani yang berdasarkan kepada Tuhan Yang Maha Esa. Cerai gugat adalah terputusnya ikatan suami istri dimana dalam hal ini sang istri yang melayangkan gugatan cerai kepada sang suami. Penelitian ini bertujuan untuk mengetahui mengapa perbedaan agama dapat digunakan sebagai alasan dalam cerai gugat di pengadilan agama Badung dan mengetahui pertimbangan majelis hakim dalam perkara di pengadilan agama Badung. Tipe penelitian yang di gunakan dalam penelitian ini yaitu Penelitian Hukum Empiris yaitu di ambil berdasarkan fakta yang terjadi di lapangan, yang didapatkan melalui penjelasan- penjelasan dari informan dan di pelajari dengan sikap hukum yang nyata atau sesuai dengan kehidupan di masyarakat. Hasil dari penelitian ini yaitu, perbedaan agama digunakan sebagai alasan dalam cerai gugat di pengadilan agama Badung sebenarnya Undang-undang perkawinan dan peraturan pelaksanaannya tidak mengatur tentang perpindahan agama (murtad) sebagai alasan putusnya perkawinan dikarenakan Negara Indonesia menganut prinsip kebebasan beragama. Akan tetapi di dalam KHI dalam Pasal 116 huruf (k) menyatakan salah satu alasan dalam perceraian, yaitu apabila salah satu pihak meninggalkan agama (murtad). 2) Pertimbangan majelis hakim dalam perkara cerai gugat di pengadilan agama badung sudah mempunyai pertimbangan-pertimbangan dan alasan yang kuat untuk di jadikan sebagai landasan dalam mengambil suatu keputusan, seperti dalam putusan perkara Nomor 0166/Pdt.G/2017/PA.Bdg. Maka dapat di simpulkan bahwa Perceraian hanya dikatakan sah setelah ada putusan pengadilan yang berkekuatan hukum tetap, serta Majelis Hakim dalam mengadili perkara perceraian yang diajukan harus mengetahui jelas fakta yang menyebabkan perpindahan agama.
\end{abstract}

Kata kunci: Cerai Gugat; Perpindahan Agama; Pengadilan Agama Badung; Undang-undang Perkawinan

\begin{abstract}
Marriage is a sacred bond because in that marriage bond there are not only physical and mental bonds but also spiritual bonds based on God Almighty. A lawsuit divorce is the breaking of the husband and wife ties, in which case the wife is the one who filed a divorce suit against the husband. This study aims to determine why religious differences can be used as an excuse for a legal divorce in the Badung religious court and to find out the judges' considerations in cases at the Badung religious court. The type of research used in this research is Empirical Legal Research, which is taken based on facts that occur in the field, which are obtained through explanations from informants and studied with real legal attitudes or in accordance with life in society. The result of this research is that religious differences are used as the reason for a legal divorce in the Badung religious court in fact the marriage law and its implementing regulations do not regulate religious conversion (murtad) as the reason for breaking up a marriage because the State of Indonesia adheres to the principle of religious freedom. However, the KHI in Article 116 letter $(k)$ states one of the reasons for divorce, namely when one of the parties leaves the religion (murtad). 2) The considerations of the panel of judges in a sue divorce case at the Badung religious court already have strong considerations and reasons to be used as a basis for making a decision, such as in the case decision Number 0166 / Pdt.G / 2017 / PA.Bdg. So it can be concluded that Divorce is only said to be valid after a court decision has permanent legal force, and the Panel of Judges in adjudicating a proposed divorce case must know clearly the facts that cause religious conversion.
\end{abstract}

Keywords: Divorce; Change of Religion; Badung Religious Court; Marriage Law 


\section{PENDAHULUAN}

Perkawinan adalah suatu hal yang mengikat dan sakral karena dalam perkawinan itu tidak Cuma terdapat ikatan lahir dan batin ataupun ikatan jasmani saja akan tetapi juga terdapat suatu ikatan rohani yang didasarkan pada Ketuhanan Yang Maha Esa, yang dimaksud disini adalah perkawinan itu tidak cuma sebatas hubungan lahiriah saja,akan tetapi melebihi dari hal itu, yakni suatu ikatan lahir batin antara laki-laki dan perempuan yang mempunyai tujuan untuk membangun rumah tangga yang bahagia dan kekal abadi berdasar atas Ketuhanan Yang Maha Esa (Sudarsono, 2006). Tujuan perkawinan yang diinginkan dalam Undang-Undang Perkawinan, jika yang dirasakan sangat tepat. Tujuannya yaitu tidak cuma dilihat dari sisi lahirnya saja tapi juga dilihat dari suatu pertautan batin antara seorang suami dan istri yang ditujukan untuk dapat membangun suatu rumah tangga yang kuat dan berbahagia dan yang sesuai dengan jalan yang diberikan oleh Tuhan Yang Maha Esa.

Karena sangat pentingnya dan sakralnya perkawinan tersebut, maka akan sangat diperlukan adanya suatu aturan yang detail dan bijak mengenai kepentingan untuk kebahagiaan dan kerukunan perkawinan agar tercipta lingkungan hidup yang baik, teratur serta tercipta ketertiban hukum pada bidang hukum perkawinan (Santoso, 2016). Pada prinsipnya Perceraian disebabkan karena suatu alasan perpindahan agama atau pindah agama setelah terjadinya pernikahan belum diatur secara jelas. Perpindahan agama tersebut hanya dapat dijadikan suatu alasan bahwa telah terjadinya percekcokan pada suatu rumah tangga yang sudah tidak bisa diselesaikan ataupun sudah tidak ada jalan keluar, oleh sebab itu seorang hakim memberikan suatu pertimbangan dan suatu putusan dengan keputusan perceraian, karena permasalah yang terjadi sudah tidak bisa diselesaikan lagi dan tidak ada titik temu yang tepat lagi. Karena pada dasarnya suatu perceraian yang diakibatkan dari tidak adanya lagi keharmonisan ditimbulkan karena banyak faktor-faktor, salah satunya yaitu adanya percekcokan yang berkepanjangan yang tidak bisa diselesaikan dan tidak bisa didamaikan dengan dasar adanya salah satu yang pindah agama tidak bisa diselesaikan lagi (Abubakar, 2020).

Menurut Hukum Islam Suatu akad perkawinan ada dua jenis: yang sah dan ada yang tidak sah. Hal ini dikarenakan, akad sah adalah sesuai dengan ketentuan agama dan akad dilaksanakan dengan syarat-syarat dan rukun-rukun yang lengkap (Jarbi, 2019). Sebaliknya akad yang tidak sah, adalah akad yang dilaksanakan tidak sesuai dengan syarat-syarat serta rukun perkawinan. Pada nyatanya ada perkawinan yang dilangsungkan cuma dengan Hukum Agama saja. Perkawinan tersebut juga sering dikatakan sebagai kawin Siri, yakni merupakan perkawinan tidak memiliki bukti asli dari perkawinan tersebut, maka perkawinan siri tersebut tidak memiliki kekuatan hukum (Anshori, 2011). Agar terjaminnya ketertiban pranata pernikahan dalam masyarakat, maka Undang-undang Perkawinan, menentukan bahwa setiap perkawinan harus dicatat oleh petugas yang berwenang. Namun kenyataan memperlihatkan fenomena yang berbeda Menurut Undang-undang Perkawinan hakikat perkawinan adalah ikatan lahir batin antara seorang pria dan seorang wanita sebagai suami istri. Terjalinnya ikatan lahir dan batin merupakan fondasi dalam membentuk dan membina keluarga yang bahagia dan kekal.

Pada jaman sekarang ini mengenai perceraian dimana seorang laki-laki pindah agama seperti kasus diatas tersebut sangat sering terjadi, meskipun belum ada suatu penelitian resmi memperkuat pernyataan itu. Akan tetapi ketika perkawinan tersebut telah berjalan beberapa tahun lamanya kejadian riil sering terjadi pada kenyataan menunjukkan bahwa banyak orang masuk ke agama islam sebelum pernikahan dan kembali ke agama masing-masing setelah pernikahan. Hal itu ketika keluar dari agama islam ataupun berpindah dari agama akan membuat seringnya terjadi permasalahan dirumah tangga. Penyebabnya adalah suatu pasangan yang ingin tetap pada agama Islam bertemu dengan masalah-masalah sering terjadi, yaitu seorang suami ataupun seorang istri sudah tidak lagi satu agama atau sudah berbeda agama, tetapi disisi berbeda perkawinan tersebut sudah berjalan sekian tahun dan sudah mempunyai seorang anak (Kusuma, 2003).

Berdasarkan uraian belakang masalah di atas, maka penelitian ini bertujuan untuk mengetahui penggunaan perbedaan agama sebagai alasan dalam cerai gugat di Pengadilan Agama Badung dan untuk mengetahui pertimbangan majelis hakim dalam perkara cerai di Pengadilan Agama Badung.

\section{METODE PENELITIAN}

Penelitian hukum adalah serangkaian kegiatan ilmiah yang didasarkan dengan suatu metode, strategi, ataupun pemikiran-pemikiran khusus yang tujuannya mempelajari satu hal atau beberapa isu hukum tertentu dengan jalan mengalisisnya (Soekanto, 2007). Ditinjau dari segala bentuknya, kita mengenal penelitian empiris dan penelitian kepustakaan. Menurut Ronny, penelitian hukum empiris merupakan 
suatu penelitian hokum yang datanya diperoleh dari data primer atau data yang didapatkan langsung dari masyarakat setempat (Soemitro, 1998).

Penelitian ini menggunakan pendekatan empiris dan yuridis normatif, yaitu dengan mengkaji atau mengalisis data sekunder yang berupa bahan-bahan hukum sekunder dengan memahami hukum sebagai perangkat peraturan atau norma-norma positif di dalam sistem perundang-undangan yang mengatur mengenai kehidupan manusia. Jadi penelitian ini dipahami sebagai penelitian kepustakaan, yaitu penelitian terhadap data sekunder. Penelitian ini termasuk penelitian hukum empiris, maka jenis data yang digunakan adalah data sekunder yang berkaitan dengan tujuan penelitian yang telah dirumuskan. Bahan hukum yang telah dikumpulkan selanjutnya diolah menggunakan metode deduktif induktif atau sebaliknya, untuk memperoleh bahan hukum yang berkualitas sesuai dengan pokok masalah yang dibahas dan akhirnya berdasarkan bahan hukum yang diperoleh dari pengumpulan maupun pengelolaan-pengelolaan tersebut di atas lalu disajikan secara deskriptif.

\section{HASIL DAN PEMBAHASAN}

1. Perbedaan Agama Digunakan sebagai Alasan dalam Cerai Gugat di Pengadilan Agama Badung

Pada dasarnya tidak terdapat suatu pengertian secara otentik mengenai perceraian, meskipun begitu tidak berarti bahwa masalah perceraian ini tidak diatur sama sekali di dalam undang-undang perkawinan. Bahkan yang terjadi justru sebaliknya, pengaturan masalah perceraian menduduki tempat paling besar, hal ini lebih jelas lagi apabila kita melihat peraturan-peraturan pelaksanaannya. Perceraian merupakan perceraian karena suatu alasan perpindahan agama atau pindah agama setelah terjadinya pernikahan belum diatur secara jelas. Perpindahan agama tersebut hanya dapat dijadikan suatu alasan bahwa telah terjadinya percekcokan pada suatu rumah tangga sudah tidak bisa diselesaiakan ataupun sudah tidak aga jalan keluar, oleh sebab itu seorang hakim memberikan suatu pertimbangan dan suatu putusan dengan keputusan perceraian, karena permasalah terjadi sudah tidak bisa diselesaikan lagi dan tidak ada titik temu tepat lagi. Karena pada dasarnya suatu perceraian diakibatkan dari tidak adanya lagi keharmonisan ditimbulkan karena banyak faktor-faktor, salah satunya yaitu adanya percekcokan yang berkepanjangan dan tidak bisa diselesaikan serta didamaikan dengan dasar adanya salah satu pindah agama.

Cerai Gugat jika dilihat pengertiannya berdasarkan peraturan perundang-undangan, agar mendapat suatu bayangan mengenai cerai gugat, maka harus diberikan penjelasan dulu tentang perceraian. Perceraian merupakan putusnya hubungan perkawinan antara suami dan istri yang sebelum terjadinya perceraian hidup sebagai suami istri. Perceraian itu dapat dibagi menjadi 2 yaitu cerai talak dan gugat. Pada tulisan jurnal ini penulis akan memberikan batasan mengenai masalah cerai gugat saja. Cerai gugat merupakan, putusnya hubungan sebagai istri. Sedangkan gugatan merupakan suatu cara agar bisa menuntut haknya lewat putusan dari pengadilan.

Adapun dalam kitab-kitab fiqh (hukum Islam) perceraian yang berdasarkan gugatan dari salah satu pihak dan dilakukan melalui proses peradilan diistilahkan dengan fasakh. Fasakh artinya merusak atau melepaskan tali ikatan perkawinan (Al-Hamdani, 2002). Dalam asas fasak merupakan hak dari seorang suami dan istri, sedangkan penerapannya adalah pihak istri lebih sering melakukan dari pada suami. Penyebabnya yaitu karena pada Agama Islam sudah diberikan hak talak pada seorang suami (Muchtar, 1987). Perceraian hanya dikatakan sah setelah ada putusan pengadilan berkekuatan hukum tetap. Dengan kata lain perceraian harus melalui pengadilan, tidak bisa tidak, Namun tidak mudah untuk menggugat ataupun memohon cerai ke pengadilan. Harus ada alasan-alasan yang cukup menurut hukum, sehingga gugatan cerai bisa dikabulkan Pengadilan.

Perkawinan satu agama sering ada dalam kehidupan masyarakat, apabila pemerintah mengatur secara jelas mengenai suatu peraturan perkawinan untuk masyarakatnya, karena penyebab seringnya terjadi perceraian adalah karena salah satu pihak tidak takut pada aturan yang ada tersebut. Sikap ambivalensi pemerintah dalam perkawinan beda agama ini terlihat dalam praktek bila tidak dapat diterima oleh Kantor Urusan Agama, dapat dilakukan di Kantor Catatan Sipil dan menganggap sah perkawinan berbeda agama dilakukan di luar negeri. Dari kenyataan yang terjadi di dalam masyarakat terhadap perkawinan beda agama, menurut aturan perundang-undangan itu sebenarnya tidak dikehendaki. Larangan perkawinan beda agama ataupun dengan agama tidak islam menunjukkan perwujudan dari pengaplikasian dari agama Islam agar tetap menghindari hal yang bersifat tidak cuma 
dunia saja akan tetapi juga berhubungan dengan hidup diakhirat nantinya.pernikahan berbeda agama yang tentunya bukan agama islam justru akan menimbulkan masalah besar yang bukan hanya tentang kesenangan sekasap mata, akan tetapi juga merupakan suatu kehidupan diakhirat nantinya. Pernikahan beda agama dalam islam seharusnya dijaga oleh Negara karena hal itu merupakan permasalahan dari umat agama islam yang merupakan masalah besar.

Adanya perceraian karena suatu alasan perpindahan agama atau pindah agama setelah terjadinya pernikahan belum diatur secara jelas. Perpindahan agama tersebut hanya dapat dijadikan suatu alasan bahwa telah terjadinya percekcokan pada suatu rumah tangga sudah tidak bisa diselesaiakan ataupun sudah tidak agar jalan keluar, oleh sebab itu seorang hakim memberikan suatu pertimbangan dan suatu putusan dengan keputusan perceraian, karena permasalah yang terjadi sudah tidak bisa diselesaikan lagi dan tidak ada titik temu yang tepat . Karena pada dasarnya suatu perceraian diakibatkan dari tidak adanya lagi keharmonisan ditimbulkan karena banyak faktor-faktor, salah satunya yaitu adanya percekcokan yang berkepanjangan dan tidak bisa diselesaikan serta tidak bisa didamaikan dengan dasar adanya salah satu yang pindah agama tidak bisa diselesaikan lagi.

Perpindahan agama dari islam ke tidak islam ataupun dari satu agama ke agama yang lain dapat menimbulkan kerenggangan dalam suatu rumah tangga dan menimbulkan masalah jangka panjang serta bisa berakhir dimeja hijau. Perpindahan agama selain menimbulkan akibat bagi anak terutama bagi status anak serta psikologis anak dan juga mengenai harta bersama. Apabila perceraian tersebut terjadi maka akan sangat mengganggu psikologis anak yang nantinya anak tersebut akan menjadi, bimbang serta bingung untuk memikirkan status dan agamanya dan dapat menyebabkan anak itu menjadi depresi . banyak faktor yang bisa menjadi penyebab terjadinya suatu perceraian, jika seorang suami ataupun seorang itu melakukan suatu perbuatan yang tidak tepat dilakukan apalagi bertentangan syariat ataupun melanggar peraturan perundang-undang menyebutkan, apabila seorang suami ataupun istri melakukan perbuatan zina, mabuk-mabukan, bermain judi, kemudian salah satu pihak baik itu suami ataupun istri pergi selama dua tahun berturut-turut.

\section{Pertimbangan Majelis Hakim dalam Perkara Cerai di Pengadilan Agama Badung}

Majelis Hakim dalam mengadili perkara perceraian diajukan para pihak suami istri berperkara harus mengetahui jelas fakta akar perselisihan dan pertengkaran terus-menerus dan tidak ada harapan hidup kembali dalam rumah tangga, adanya peralihan agama atau murtad sehingga dilanjutkan pembuktian baik alat bukti dan saksi diajukan oleh para pihak berperkara. Membuktikan adalah menyakinkan Hakim tentang kebenaran dalil yang di kemukakan di muka sidang dalam suatu sengketa. Kewenangan Hakim Pengadilan Agama pada saat mengadili suatu perceraian yang penyebabnya karena perpindahan agama suami maka berdasakan pada asas personalitas keislaman penerapan asas tersebut adalah kesatuan hubungan tidak dapat dipisahkan hubungan hukumnya yang mana suatu kesempurnaan dan kemutlakan asas personalitas tersebut harus disuport dengan unsur hubungan hukum berdasarkan atas hukum Islam, maka sengketanya mutlak dan absolut tunduk serta merupakan kewenangan dari pengadilan agama, kewenangan absolut itu merupakan suatu kewenangan berdasarkan atas dasar kekuasaan absolut Pengadilan Agama untuk dapat memutus kasus perceraian mana akad nikahnya berdasarkan atas hukum Islam, karena pada perkara perceraian diatas tersebut akad nikahnya dilakukan diKUA Denpasar Barat, Badung, Bali maka yang berwenang mengadili adalah Pengadilan Agama Badung. Kewenangan dari Hakim pada Pengadilan Agama dalam memutus perkara cerai apabila penyebabnya kare perpindahan agama dari pihak suami maka berpedoman dengan asas personalitas keislaman yang sudah ditentukan.

Pengadilan Agama mempunyai kewenangan untuk mengadili seseorang yang telah melakukan perpindahan agama, dimana dijadikan dasar untuk ukuran dalam menentukan berwenang atau tidak Pengadilan Agama bersangkutan yaitu bukan didasarkan pada agama yang dipercaya saat masalah itu timbul. Meskipun perbedaan agama tersebut bisa dijadikan dasar dari perceraian, akan tetapi hubungan hukum perkawinan tersebut tetap memiliki kekuatan hukum sampai ada putusan dari Pengadilan berwenang membatalkan perkawinan itu. Maka, asas personalitas Keislaman dinilai sebagai suatu fundamen penegakkan dilingkungan Peradilan. Hakim Pengadilan Agama Badung dalam Memutus suatu perkara Perceraian dengan alasan suami melakukan murtad atau berubah keyakinan harus memiliki suatu pertimbangan serta alasan logis agar bisa dijadikan landasan pada saat memutus suatu perkara, agar tidak terjadinya suatu kekeliruan saat memutus suatu perkara serta 
tidak menimbulkan kerugian antara penggugat ataupun tergugat seperti dalam putusan perkara Nomor 0166/Pdt.G/2017/PA.Bdg yang menyatakan bahwa tergugat melakukan murtad atau perpidah keyakinan dari Islam ke Kristen sehingga penggugat mengajukan permohonan gugatan kepada Pengadilan Agama Badung dan penggugat berharap agar Majelis Hakim dapat memutuskan perkara seadil-adilnya serta memohon untuk mengabulkan seluruh gugatan penggugat. Apabila suatu alasan perpindahan agama atau pindah agama setelah terjadinya pernikahan belum diatur secara jelas. oleh sebab itu seorang hakim memberikan suatu pertimbangan dan suatu putusan dengan keputusan perceraian, karena permasalah yang terjadi sudah tidak bisa diselesaikan lagi dan tidak ada titik temu yang tepat lagi. Karena pada dasarnya suatu perceraian yang diakibatkan dari tidak adanya lagi keharmonisan ditimbulkan karena banyak faktor.

\section{SIMPULAN DAN SARAN}

\section{Simpulan}

Dari penjelasan di atas, dapat disimpulkan bahwa perbedaan agama dapat di gunakan sebagai alasan dalam cerai gugat di pengadilan agama, dapat dikatakan bahwa Perceraian hanya dikatakan sah setelah ada putusan pengadilan berkekuatan hukum tetap. Ketika suatu perkawinan tersebut telah berjalan beberapa tahun lamanya kejadian riil yang sering terjadi pada kenyataan menunjukkan bahwa banyak orang masuk ke agama islam sebelum pernikahan dan kembali ke agama masing-masing setelah pernikahan. Hal itu ketika keluar dari agama islam ataupun berpindah dari agama akan membuat seringnya terjadi permasalahan- permasalahan dirumah tangga. Penyebabnya adalah suatu pasangan yang ingin tetap pada agama Islam bertemu dengan masalah-masalah sering terjadi, yaitu seorang suami ataupun seorang istri sudah tidak lagi satu agama atau sudah berbeda agama, tetapi disisi berbeda perkawinan tersebut sudah berjalan sekian tahun dan sudah mempunyai seorang anak maka murtad dapat di gunakan sebagai alasan dalam suatu perceraian. Kemudian, mengenai pertimbangan majelis hakim dalam perkara cerai gugat di pengadilan agama, Majelis Hakim dalam mengadili perkara perceraian diajukan para pihak suami istri yang berperkara harus mengetahui jelas fakta akar perselisihan dan pertengkaran terus-menerus dan tidak ada harapan hidup kembali dalam rumah tangga, adanya peralihan agama atau murtad sehingga dilanjutkan pembuktian baik alat bukti dan saksi diajukan oleh para pihak berperkara. Membuktikan adalah menyakinkan Hakim tentang kebenaran dalil yang di kemukakan di muka sidang dalam suatu sengketa dan dari bukti-bukti tersebut hakim dapat mempertimbangkan keputusannya.

\section{Saran}

Adapun saran yang hendak disampaikan yakni, hendaknya majelis hakim di lingkungan Pengadilan Agama Badung, dalam memutuskan suatu perkara tidak hanya mendasarkan pada peraturan perundang-undangan yang berlaku di Indonesia saja (hukum positif), tapi juga menggunakan hukum syara' (terutama al-Qur'an sebagai sumber utama hukum Islam). Mengingat Pengadilan Agama adalah peradilan Islam di Indonesia yang diberi hak oleh pemerintah untuk menyelesaikan perkara tertentu di kalangan orang yang beragama Islam dan secara hukum Islam sesuai dengan wewenang dan kekuasaannya. Kemudian, majelis hakim di Pengadilan Agama Badung harus lebih teliti memeriksa perkara dan mengadili suatu perkara sehingga tidak terjadi kesalahan yang dapat merugikan para pihak yang bersengketa, Hakim juga harus mengutamakan perdamaian terlebih dahulu dalam menyelesaikan perkara.

\section{DAFTAR PUSTAKA}

Abubakar, M. (2020). Meningkatnya Cerai Gugat Pada Mahkamah Syar'iyah. Kanun Jurnal Ilmu Hukum, 22(2), 301-322.

Al-Hamdani. (2002). Risalah Nikah (Hukum Perkawinan Islam). Pustaka Amani.

Anshori, A. G. (2011). Hukum Perkawinan Islam (Persfektif Fikih dan Hukum Positif). UII Press.

Jarbi, M. (2019). Pernikahan Menurut Hukum Islam. PENDAIS, 1(1), 56-68.

Kusuma, H. H. (2003). Hukum Perkawinan Indonesia Menurut Perundangan, Hukum Adat, Hukum Agama. Mandar Maju.

Muchtar, K. (1987). Asas-Asas Hukum Islam Tentang Perkawinan. Bulan Bintang.

Santoso. (2016). Hakekat Perkawinan Menurut Undang-Undang Perkawinan, Hukum Islam dan Hukum Adat. Yudisia, 7(2), 412-434. 
Soekanto, S. (2007). Pengantar Penelitian Hukum. UI Press.

Soemitro, R. H. (1998). Metodologi Penelitian Hukum dan Jurumetri. Ghalia Indonesia.

Sudarsono. (2006). Hukum Perkawinan Nasional (cet. III). Rineka Cipta. 